\title{
Social jetlag in health and behavioral research: a systematic review
}

This article was published in the following Dove Press journal:

ChronoPhysiology and Therapy

8 May 2017

Number of times this article has been viewed

\section{Juliana Castilhos Beauvalet ${ }^{1,2}$ \\ Caroline Luísa Quiles ${ }^{1,2}$ \\ Melissa Alves Braga de Oliveira ${ }^{1,2}$ \\ Carlos Augusto Vieira Ilgenfritz' \\ Maria Paz Loayza Hidalgo'-3 \\ André Comiran Tonon'}

'Laboratório de Cronobiologia e Sono, Hospital de Clínicas de Porto Alegre (HCPA), Universidade Federal do Rio Grande do Sul (UFRGS),

Porto Alegre, RS, Brazil; ${ }^{2}$ Postgraduate Program in Psychiatry and Behavioral Sciences, Medical School, Universidade Federal do Rio Grande do Sul (UFRGS), Porto Alegre, RS, Brazil; ' ${ }^{\text {Department }}$ of Psychiatry and Forensic Medicine, Medical School, Universidade Federal do Rio Grande do Sul (UFRGS), Porto Alegre, RS, Brazil

\section{Video abstract}

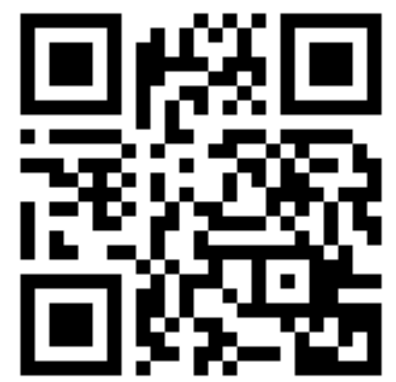

Point your SmartPhone at the code above. If you have a QR code reader the video abstract will appear. Or use: http://youtu.be/YTDShcW9DRA
Correspondence: André Comiran Tonon Laboratório de Cronobiologia e Sono do Hospital de Clínicas de Porto Alegre (HCPA), Universidade Federal do Rio Grande do Sul (UFRGS), Rua Ramiro Barcelos, 2350, Centro de Pesquisa Clínica, room 21617, Porto Alegre, RS 90035-903, Brazil

Tel +55 5I 33598849

Email andrectonon@gmail.com
Background: Even though light is considered the main cue that entrains inner biological rhythms according to circadian environmental rhythms, social organizations have the capacity to take the body "out of sync". An emergent field of research on the topic refers to what has been described as social jetlag, the biological misalignment that arises from alternated work and free days. However, to the present moment, there is still controversial evidence on the effects of such a phenomenon to human health.

Objective: The aim of this study was to identify current peer-reviewed evidence of the health and behavioral risks associated with social jetlag.

Method: We conducted a systematic review of the literature on PubMed, Scopus, Embase and LILACS electronic databases using the terms "social AND (jet lag OR jetlag)". The search was finalized on August 22, 2016, resulting in 26 research articles included in the review.

Results and discussion: Our results point to a variety of health and behavioral outcomes that seem to be associated with the mismatch existent between work or study days and free days. They are epilepsy, minor psychiatric symptoms, aggression and conduct problems, mood disorders, cognitive impairment (eg, work and academic performance), substance use, cardiometabolic risk and adverse endocrine profiles. However, these results must be analyzed with caution because of the high methodological heterogeneity, the significant risk of bias of analyzed studies, as well as the low similarity among the populations described.

Keywords: chronobiology, biological rhythms, sleep, shift work

\section{Background}

Living beings are regulated by oscillating biological systems that orchestrate physiologic and behavioral events, synchronizing them to external signals such as light-dark cycles and social routines. ${ }^{1}$ Although several studies support that light is still the main zeitgeber (from German, zeit $=$ time, geber $=$ giver $),{ }^{2}$ that is, the main environmental cue that entrains our bodily rhythms, a growing amount of evidence suggests that social cues might be of major importance influencing biological rhythms. ${ }^{3,4}$

Social routines are organized into conventional time periods (eg, business hours from 8 a.m. to 6 p.m. in most cities in Brazil). These routines are influenced by several factors, which include the demand for increased productivity and competitiveness, public security and other cultural aspects such as religion and ethnicity. Therefore, such routines are not in total synchrony with the endogenous circadian (from Latin, circa $=$ about, diem $=$ a day) rhythmicity of all individuals and, sometimes, not even with the natural day-night transitions. ${ }^{5}$ Modern lifestyles changed the way we interact with our surroundings. The need to live in a society requires submission to these rules 
and structures, leading to obvious benefits from cooperation as a group, but providing situations that could represent a risk for some individuals who have to abandon photoentrainment (entrainment to the exogenous light-dark cycle) and follow routines in disagreement with their physiologic rhythmicity. ${ }^{6}$

Each person presents an individual phase of entrainment to the external days, referred to as chronotypes, which reflects on optimal daily times for different activities. ${ }^{7}$ This derives from a combination of genetic factors, development and environment, which determine the timing of our endogenous clock. ${ }^{8}$ Even though the majority of individuals are classified as intermediate chronotypes with no strong preferences, the distribution can vary from extreme early to extreme late chronotypes. The standard organization of our society favors those who tend to wake and sleep earlier (early types) and obliges those who tend to wake and sleep later (late types) to follow routines that differ from their internal time. In addition, the demand for productivity led to the emergence of practices such as shift work, which implies exposition to unnatural patterns of light-dark cycles. An increasing number of studies suggests that disruption of normal circadian rhythms can lead to a variety of health and behavioral outcomes, such as metabolic syndrome, obesity, ${ }^{9,10}$ breast cancer ${ }^{11}$ and mood disorders. ${ }^{12}$ This relevant disturbance on circadian rhythms is also known as chronodisruption. ${ }^{13}$ Several studies focus on sleep parameters as means to identify the mechanisms through which circadian disruption occurs. ${ }^{14,15}$ Despite the scientific development to the present moment, there is still no consensus on what it is that we should call "optimal sleep". ${ }^{16,17}$ Most studies focus on sleep quality and daytime sleepiness, but these are not the only variables that are relevant to the study of animal's ideal sleep. In this scenario, one emergent field of research pertains to what has been called social jetlag (SJL). This phenomenon has been initially described as a biological misalignment that arises from alternated work and free days, ${ }^{18}$ considering the discrepancies between the social and the biological clock that lead to sleep and wakefulness at inappropriate circadian times. ${ }^{19} \mathrm{SJL}$ has been studied in many health-related researches, measured by either subjective or objective assessments (eg, reported sleep times and actigraphy, respectively). The conventional formula to calculate SJL subtracts the Midpoint of Sleep on Work days from the Midpoint of Sleep on Free days (MSF).

A growing amount of evidence suggests that SJL is related to a series of conditions commonly associated with chronodisruption. However, the association of SJL to human health is still controversial, since no systematic review on the topic has been performed till now. Through a systematic review of the literature, we aimed to identify the current evidence of health and behavioral risks associated with SJL.

\section{Method}

\section{Search method}

We conducted a systematic review of the literature on PubMed, Scopus, Embase and Latin American and Caribbean Health Science Literature (LILACS) using the terms "social AND (jet lag OR jetlag)" on the default search fields of each electronic database. No advanced search tool was employed. We searched for peer-reviewed papers reporting empirical studies including data on health and behavioral outcomes associated with SJL in different populations. Given the heterogeneity of the body of literature on the topic, we included all studies with at least one health or behavioral outcome associated with SJL. However, studies that solely analyzed sleep parameters or circadian patterns, but did not assess health or behavioral outcomes were excluded from the review.

Due to the restricted number of empirical studies, we did not establish a minimum number of participants included in the studies. This way, we could avoid missing data from small sample studies. Looking for the highest methodological quality, we excluded non-peer-reviewed references and unpublished data. We retained only observational studies with no language restriction. Review studies were excluded.

The search was finalized on August 22, 2016. Two authors (ACT and JCB) independently and blindly performed the search and screening of abstracts against the eligibility criteria. The other four authors were divided in pairs and they blindly read all full-length papers initially selected, applying a more rigorous eligibility. Any disagreement among authors was resolved by consensus. Figure 1 displays the systematic review process conducted according to Cochrane guidelines. ${ }^{20}$

\section{Risk of bias assessment}

In order to determine the level of evidence of included studies, six questions were proposed and blindly answered for each study by the same pairs of reviewers that read the full-length papers. Any disagreement among authors was resolved by consensus. Questions assessed the risk of selection bias (Q1 and Q2), detection bias (Q3), attrition bias (Q4) and reporting bias (Q5). An additional question (Q6) was included to assess biases not addressed in the previous questions. They are:

1. Q1: General characteristics of the individuals are assessed (eg, demographics, possible confounding factors)? If groups are compared, is there any significant difference among them? 


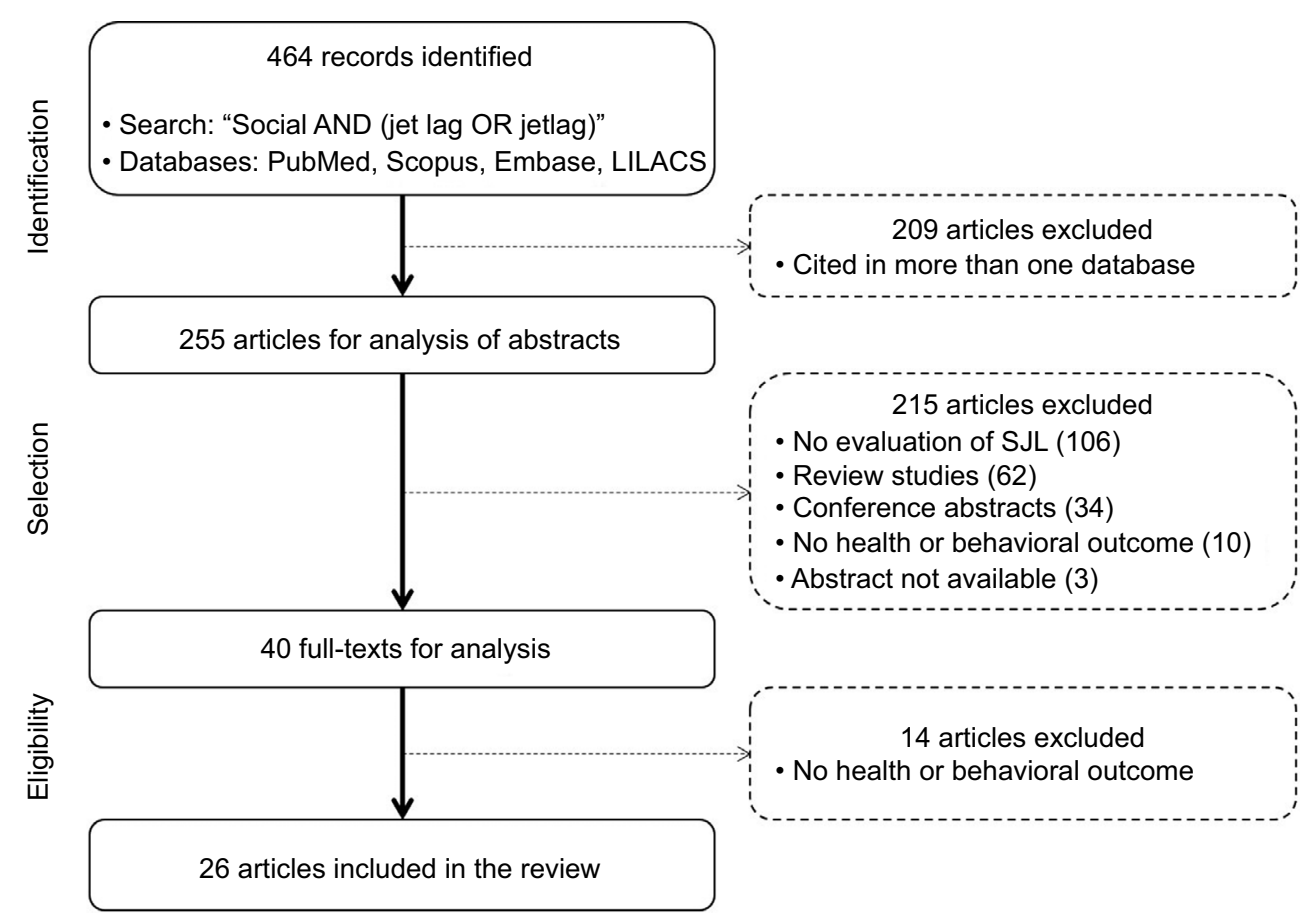

Figure I Systematic review process.

Abbreviations: SJL, social jetlag; LILACS, Latin American and Caribbean Health Science Literature.

2. Q2: Is there significant exclusion/noninclusion of individuals that could compromise results validity?

3. Q3: Are outcomes assessed ensuring internal validity of the study?

4. Q4: Are there significant withdrawals from the study?

5. Q5: Results reported are in agreement to the hypothesis?

6. Q6: Is there any additional risk of bias that could compromise study findings?

Three possible answers could be given to each question: "high risk of bias", "low risk of bias" or "inability to determine due to lack of information". The level of evidence for each study can be seen in Figure 2.

\section{Results and discussion}

In the past years, the term "social jetlag" has been increasingly used. Our initial search shows that, even though many articles were excluded from this review because they did not measure SJL, a significant part of studies mentioned it throughout the text.

\section{Excluded studies and terminology}

Several studies retrieved in our search correlate SJL with sleep disturbances. Although sleep disturbances are known to affect health and behavior, ${ }^{6}$ we cannot presume a direct causal relationship between such outcomes and SJL, which appears mostly as a variable that characterizes the study samples. Thus, we chose to exclude studies that did not explicitly assess illness

\begin{tabular}{|c|c|c|c|c|c|c|}
\hline & Q1 & Q2 & Q3 & Q4 & Q5 & Q6 \\
\hline Wittmann et al $2006^{18}$ & $?$ & $?$ & $?$ & + & - & $?$ \\
\hline Levandovski et al $2011^{29}$ & + & + & $?$ & - & + & + \\
\hline Roenneberg et al $2012^{21}$ & - & $?$ & $?$ & + & + & $?$ \\
\hline Johnsen et al $2013^{22}$ & - & - & $?$ & - & + & + \\
\hline Kantermann et al $2013^{27}$ & + & $?$ & $?$ & $?$ & + & $?$ \\
\hline Randler and Vollmer $2013^{43}$ & $?$ & + & $?$ & + & + & - \\
\hline Schimitt et al $2013^{35}$ & - & + & $?$ & $?$ & + & + \\
\hline de Souza and Hidalgo $2015^{12}$ & + & $?$ & $?$ & $?$ & + & + \\
\hline Haraszti et al $2014^{40}$ & + & - & $?$ & - & + & $?$ \\
\hline Kantermann et al $2014^{25}$ & + & $?$ & $?$ & - & + & $?$ \\
\hline Miller et al $2015^{44}$ & + & - & + & - & + & $?$ \\
\hline Rutters et al $2014^{28}$ & + & + & $?$ & $?$ & + & $?$ \\
\hline Borisenkov et al $2015^{32}$ & + & + & $?$ & + & + & $?$ \\
\hline Diaz-Morales and Escribano $2015^{39}$ & $?$ & + & - & + & + & $?$ \\
\hline Jankowski $2015^{34}$ & - & $?$ & $?$ & - & + & $?$ \\
\hline Lin and $Y i 2015^{37}$ & + & $?$ & - & $?$ & + & + \\
\hline Parsons et al $2015^{35}$ & $?$ & + & + & $?$ & + & + \\
\hline Tavernier et al $2015^{42}$ & + & + & - & + & + & $?$ \\
\hline Wong et al $2015^{26}$ & + & - & + & + & + & $?$ \\
\hline Choi et al $2016^{45}$ & $?$ & $?$ & $?$ & + & + & $?$ \\
\hline Diaz-Morales et al $2016^{36}$ & $?$ & + & - & + & + & $?$ \\
\hline Kolomeichuk et al $2016^{38}$ & $?$ & + & $?$ & + & $?$ & - \\
\hline Polugrudov et al $2016^{24}$ & + & + & $?$ & + & + & $?$ \\
\hline Sheaves et al $2016^{30}$ & $?$ & - & $?$ & + & $?$ & - \\
\hline Silva et al $2016^{46}$ & $?$ & - & $?$ & + & $?$ & - \\
\hline Yong et al $2016^{41}$ & - & $?$ & $?$ & + & + & $?$ \\
\hline
\end{tabular}

Figure 2 Risk of bias assessment.

Notes: Questions I and 2 (QI and Q2) indicate seletion bias, Q3 indicates detection bias, Q4 indicates attrition bias, Q5 indicates reporting bias, and Q6 indicates any additional bias. Crosses represent low risk of bias; dashes, high risk of bias; and interrogation marks, an inability to determine bias due to lack of information. 
Table I Summary of findings

\begin{tabular}{|c|c|c|c|c|c|c|c|}
\hline Study & Population & $\begin{array}{l}\text { Age range/mean } \\
\text { age (SD) }\end{array}$ & $\begin{array}{l}\text { Number } \\
\text { of males/ } \\
\text { females }\end{array}$ & $\begin{array}{l}\text { Geographic } \\
\text { location }\end{array}$ & $\begin{array}{l}\text { Sample } \\
\text { size }\end{array}$ & Design & $\begin{array}{l}\text { Instrument } \\
\text { used to } \\
\text { define SJL }\end{array}$ \\
\hline $\begin{array}{l}\text { Wittmann et al } \\
2006^{18}\end{array}$ & $\begin{array}{l}\text { General } \\
\text { population }\end{array}$ & |4-94 & $190 / 303$ & $\begin{array}{l}\text { Germany } \\
\text { (midlatitude) }\end{array}$ & 501 & Cross-sectional & MCTQ \\
\hline $\begin{array}{l}\text { Levandovski et al } \\
201 I^{29}\end{array}$ & Rural population & 44.1 (13.4) & |340/27| | & $\begin{array}{l}\text { Southern Brazil } \\
\text { (subtropical) }\end{array}$ & 4051 & Cross-sectional & MCTQ \\
\hline $\begin{array}{l}\text { Roenneberg et al } \\
2012^{21}\end{array}$ & $\begin{array}{l}\text { General Internet- } \\
\text { using public }\end{array}$ & $16-65$ & $\mathrm{NI}$ & $\begin{array}{l}\text { Primarily } \\
\text { central Europe } \\
\text { (midlatitude) }\end{array}$ & 64,110 & Cross-sectional & MCTQ \\
\hline Johnsen et al $2013^{22}$ & $\begin{array}{l}\text { General } \\
\text { population }\end{array}$ & $30-65$ & $3053 / 3356$ & $\begin{array}{l}\text { Northern Norway } \\
\text { (arctic) }\end{array}$ & 6412 & Cross-sectional & MCTQ \\
\hline $\begin{array}{l}\text { Kantermann et al } \\
2013^{27}\end{array}$ & $\begin{array}{l}\text { Shift workers of } \\
\text { a steel factory }\end{array}$ & $42(7.6)$ & $77 / 0$ & $\begin{array}{l}\text { Belgium } \\
\text { (midlatitude) }\end{array}$ & 77 & Cross-sectional & MCTQshift \\
\hline $\begin{array}{l}\text { Randler and Vollmer } \\
2013^{43}\end{array}$ & $\begin{array}{l}\text { Undergraduate } \\
\text { students }\end{array}$ & $23.8(3.7)$ & $320 / 112$ & $\begin{array}{l}\text { Germany } \\
\text { (midlatitude) }\end{array}$ & 432 & Cross-sectional & Open questions \\
\hline Schimitt et al $2013^{35}$ & $\begin{array}{l}\text { Day shift } \\
\text { workers }\end{array}$ & $18-60$ & $\mathrm{NI}$ & $\begin{array}{l}\text { Southern Brazil } \\
\text { (subtropical) }\end{array}$ & 143 & Cross-sectional & MCTQ \\
\hline $\begin{array}{l}\text { de Souza and } \\
\text { Hidalgo, } 2015^{12}\end{array}$ & Adolescents & |4.7 (I.86) & $104 / 247$ & $\begin{array}{l}\text { Southern Brazil } \\
\text { (subtropical) }\end{array}$ & 351 & Cross-sectional & MCTQ \\
\hline Haraszti et al $2014^{40}$ & $\begin{array}{l}\text { Undergraduate } \\
\text { students }\end{array}$ & $21.23(3.12)$ & $241 / 512$ & $\begin{array}{l}\text { Hungary } \\
\text { (midlatitude) }\end{array}$ & 753 & Cohort & MCTQ \\
\hline $\begin{array}{l}\text { Kantermann et al } \\
2014^{25}\end{array}$ & $\begin{array}{l}\text { Male shift } \\
\text { workers }\end{array}$ & $43.3(6.8)$ & $43 / 0$ & $\begin{array}{l}\text { Belgium } \\
\text { (midlatitude) }\end{array}$ & 43 & Cross-sectional & MCTQshift \\
\hline Miller et al $2015^{44}$ & $\begin{array}{l}\text { General } \\
\text { population }\end{array}$ & $42.89(7.33)$ & $|97 / 21|$ & $\begin{array}{l}\text { Northern USA } \\
\text { (midlatitude) }\end{array}$ & 408 & Cross-sectional & Actigraphy \\
\hline Rutters et al $2014^{28}$ & $\begin{array}{l}\text { University students } \\
\text { and employees }\end{array}$ & $\begin{array}{l}\text { Male: } 28.6(9.4) \\
\text { Female: } 26.9(8.5)\end{array}$ & $67 / 78$ & $\begin{array}{l}\text { The Netherlands } \\
\text { (midlatitude) }\end{array}$ & 145 & Cross-sectional & $\begin{array}{l}\text { Adapted } \\
\text { MCTQ }\end{array}$ \\
\hline $\begin{array}{l}\text { Borisenkov et al } \\
2015^{32}\end{array}$ & $\begin{array}{l}\text { High school } \\
\text { students }\end{array}$ & I4.8 (2.6) & $1517 / 1918$ & $\begin{array}{l}\text { Northern European } \\
\text { Russia (subarctic } \\
\text { and arctic) }\end{array}$ & 3435 & Cross-sectional & MCTQ \\
\hline $\begin{array}{l}\text { Díaz-Morales and } \\
\text { Escribano } 2015^{39}\end{array}$ & $\begin{array}{l}\text { High school } \\
\text { students }\end{array}$ & I4.I (1.48) & $37 I / 425$ & Spain (midlatitude) & 796 & Cross-sectional & $\begin{array}{l}\text { School Sleep } \\
\text { Habits Survey }\end{array}$ \\
\hline Jankowski $2015^{34}$ & $\begin{array}{l}\text { Undergraduate } \\
\text { students }\end{array}$ & $22.2(1.9)$ & $16 / 101$ & $\begin{array}{l}\text { Poland } \\
\text { (midlatitude) }\end{array}$ & 117 & Cohort & Open questions \\
\hline Lin and $Y i 2015^{37}$ & $\begin{array}{l}\text { Junior-high } \\
\text { school students }\end{array}$ & $\begin{array}{l}\text { Wave 2: I4.3 (0.48) } \\
\text { Wave 3: I5.3 (0.47) } \\
\text { Wave 4: I6.3 (0.47) }\end{array}$ & $1368 / 1315$ & $\begin{array}{l}\text { Taiwan } \\
\text { (subtropical) }\end{array}$ & 2683 & Cohort & Open questions \\
\hline Parsons et al $2015^{23}$ & $\begin{array}{l}\text { General } \\
\text { population }\end{array}$ & 38 & $\mathrm{NI}$ & $\begin{array}{l}\text { New Zealand } \\
\text { (midlatitude) }\end{array}$ & 815 & Cross-sectional & MCTQ \\
\hline $\begin{array}{l}\text { Tavernier et al } \\
2015^{42}\end{array}$ & $\begin{array}{l}\text { Undergraduate } \\
\text { students }\end{array}$ & I9.01 (0.9) & $268 / 674$ & $\begin{array}{l}\text { Southwestern } \\
\text { Canada } \\
\text { (midlatitude) }\end{array}$ & 942 & Cohort & $\begin{array}{l}\text { Adapted } \\
\text { MCTQ }\end{array}$ \\
\hline Wong et al $2015^{26}$ & $\begin{array}{l}\text { General } \\
\text { population }\end{array}$ & $42.7(7.4)$ & $210 / 237$ & $\begin{array}{l}\text { Northern USA } \\
\text { (midlatitude) }\end{array}$ & 447 & Cross-sectional & Actigraphy \\
\hline Choi et al $2016^{45}$ & $\begin{array}{l}\text { Epileptic and } \\
\text { healthy control } \\
\text { participants }\end{array}$ & $\begin{array}{l}\text { Epilepsy: } 33.0 \text { (8.24) } \\
\text { Control: } 33.6(8.80)\end{array}$ & $155 / 135$ & $\begin{array}{l}\text { South Korea } \\
\text { (midlatitude) }\end{array}$ & 290 & Cross-sectional & Sleep diary \\
\hline
\end{tabular}




\begin{tabular}{|c|c|c|c|}
\hline $\begin{array}{l}\text { Calculation } \\
\text { of SJL }\end{array}$ & $\begin{array}{l}\text { Calculation of } \\
\text { midpoint of sleep }\end{array}$ & Outcomes related to SJL & Study results ${ }^{a}$ \\
\hline MSF-MSW & $\begin{array}{l}\text { Midpoint between sleep } \\
\text { onset and sleep end }\end{array}$ & Sleep quality, use of stimulants & Higher probability of smoking \\
\hline MSF-MSW & $\begin{array}{l}\text { Midpoint between sleep } \\
\text { onset and sleep end }\end{array}$ & Depression & $\begin{array}{l}\text { Higher BDlas (BDI corrected for age and sex) scores when } \\
\mathrm{SJL}>2 \text { hours independent of smoking status; age group } 3 \mathrm{I}-40 \\
\text { years with mild to severe BDI scores suffered from higher SJL }\end{array}$ \\
\hline MSF-MSW & $\begin{array}{l}\text { Midpoint between sleep } \\
\text { onset and sleep end }\end{array}$ & Obesity & $\begin{array}{l}\text { Higher probability of being overweight }(B M I \geq 25) \text { and weight } \\
\text { increase in the overweight group }\end{array}$ \\
\hline MSFsc-MSW & $\begin{array}{l}\text { Midpoint between sleep } \\
\text { onset and sleep end }\end{array}$ & Obesity & $\begin{array}{l}\text { No association between } \mathrm{SJ}, \mathrm{BMI} \geq 25 \mathrm{~kg} / \mathrm{m}^{2} \text {, waist-to-hip ratio } \\
\text { and abdominal obesity when controlled for health, lifestyle and } \\
\text { biological factors }\end{array}$ \\
\hline MSF-MSW & $\begin{array}{l}\text { Midpoint between sleep } \\
\text { onset and sleep end }\end{array}$ & Atherosclerotic risk & $\begin{array}{l}\text { Positive correlation with heart rate, but no association with } \\
\text { arterial stiffness measured by pulse wave velocity }\end{array}$ \\
\hline MSF-MSW & $\begin{array}{l}\text { Midpoint between sleep } \\
\text { onset and sleep end }\end{array}$ & Aggression & $\begin{array}{l}\text { Higher physical and verbal aggression scores measured by } \\
\text { Buss-Perry Aggression Questionnaire }\end{array}$ \\
\hline MSF-MSW & $\begin{array}{l}\text { Midpoint between sleep } \\
\text { onset and sleep end }\end{array}$ & $\begin{array}{l}\text { Social rhythm and minor psychiatric } \\
\text { symptoms }\end{array}$ & $\begin{array}{l}\text { Inverse correlation with Index of Regularity of activities in } \\
\text { bivariate, but not in multivariate analysis; no associations with } \\
\text { SRQ-20 }\end{array}$ \\
\hline MSF-MSW & $\begin{array}{l}\text { Midpoint between sleep } \\
\text { onset and sleep end }\end{array}$ & Depression & $\begin{array}{l}\text { No association with depressive symptoms assessed by BDI } \\
\text { scores }\end{array}$ \\
\hline MSF-MSW & $\begin{array}{l}\text { Midpoint between sleep } \\
\text { onset and sleep end }\end{array}$ & Academic performance & $\begin{array}{l}\text { Poor academic grades during lecture term and better } \\
\text { performance during exams period (no weekly fixed obligations) }\end{array}$ \\
\hline MSF-MSW & $\begin{array}{l}\text { Midpoint between sleep } \\
\text { onset and sleep end }\end{array}$ & Metabolic risk & $\begin{array}{l}\text { No associations with blood glucose, insulin, apolipoprotein-A } \\
\text { and }-B, H D L \text { and } L D L \text {, total cholesterol, triglycerides, minimally } \\
\text { oxidized LDL, C-reactive protein, IL-8 and } 25-O H D\end{array}$ \\
\hline MSF-MSW & $\begin{array}{l}\text { Midpoint between sleep } \\
\text { onset and sleep end }\end{array}$ & $\begin{array}{l}\text { Mediation in the relationship between } \\
\text { positive affect rhythms and chronotype }\end{array}$ & $\begin{array}{l}\text { No significance found in correlations of acrophase and } \\
\text { amplitude of PANAS with CSM }\end{array}$ \\
\hline MSF-MSW & $\begin{array}{l}\text { Midpoint between sleep } \\
\text { onset and sleep end }\end{array}$ & $\begin{array}{l}\text { Adverse endocrine and cardiovascular risk } \\
\text { profile }\end{array}$ & $\begin{array}{l}\text { Subjects with } \geq 2 \text { hours SJL had higher } 5 \text { hour cortisol levels, } \\
\text { were more often physically inactive and had higher resting } \\
\text { heart rate, compared with those who had } \leq I \text { hour SJL; no } \\
\text { differences in BMI, waist circumference and blood pressure }\end{array}$ \\
\hline MSF-MSW & $\begin{array}{l}\text { Midpoint between sleep } \\
\text { onset and sleep end }\end{array}$ & Winter seasonal affective disorder & Higher winter scores of SPAQ in women \\
\hline MSF-MSW & $\begin{array}{l}\text { Midpoint between } \\
\text { bedtime and rising time }\end{array}$ & $\begin{array}{l}\text { Cognitive performance and academic } \\
\text { achievement }\end{array}$ & $\begin{array}{l}\text { Lower general cognitive ability; lower scores on Thurstone's } \\
\text { primary mental abilities (except for verbal fluency); lower GPA. } \\
\text { Greater effects on women }\end{array}$ \\
\hline MSF-MSW & $\begin{array}{l}\text { Midpoint between sleep } \\
\text { onset and sleep end }\end{array}$ & Psychological well-being & $\begin{array}{l}\text { Positive association with nervous mood, assessed by TA } \\
\text { subscale of UMACL }\end{array}$ \\
\hline $\begin{array}{l}\text { Weekend } \\
\text { bedtime- } \\
\text { weekday }\end{array}$ & $\begin{array}{l}\text { SJL calculation did not } \\
\text { use midpoint of sleep }\end{array}$ & Conduct problems & $\begin{array}{l}\text { Poor academic performance and defiant attitude assessed by } \\
\text { open questions }\end{array}$ \\
\hline $\begin{array}{l}\text { bedtime } \\
\text { MSF-MSW }\end{array}$ & $\begin{array}{l}\text { Midpoint between sleep } \\
\text { onset and sleep end }\end{array}$ & Obesity and metabolic disorder & $\begin{array}{l}\text { Higher BMI and fat mass; higher probability of being obese and } \\
\text { meet the criteria for metabolic syndrome }\end{array}$ \\
\hline MSF-MSW & $\begin{array}{l}\text { Midpoint between } \\
\text { bedtime and wake time }\end{array}$ & Academic adjustment and substance use & $\begin{array}{l}\text { No predictive effect on substance use or academic adjustment } \\
\text { assessed by a subscale of the SACQ; greater substance use was } \\
\text { a significant predictor of SJL }\end{array}$ \\
\hline MSF-MSW & $\begin{array}{l}\text { Midpoint between sleep } \\
\text { onset and sleep end }\end{array}$ & Cardiometabolic risk & $\begin{array}{l}\text { Higher triglycerides, fasting insulin, insulin resistance estimated } \\
\text { by the HOMA-IR, waist circumference and BMI; lower HDL }\end{array}$ \\
\hline MSF-MSW & $\begin{array}{l}\text { Midpoint between sleep } \\
\text { onset and sleep end }\end{array}$ & $\begin{array}{l}\text { Prevalence in epileptic compared to } \\
\text { healthy control subjects and among } \\
\text { epilepsy subtypes }\end{array}$ & $\begin{array}{l}\text { Larger SJL in healthy controls and in general epilepsy compared } \\
\text { to focal epilepsy }\end{array}$ \\
\hline
\end{tabular}

(Continued) 
Table I (Continued)

\begin{tabular}{|c|c|c|c|c|c|c|c|}
\hline Study & Population & $\begin{array}{l}\text { Age range/mean } \\
\text { age (SD) }\end{array}$ & $\begin{array}{l}\text { Number } \\
\text { of males/ } \\
\text { females }\end{array}$ & $\begin{array}{l}\text { Geographic } \\
\text { location }\end{array}$ & $\begin{array}{l}\text { Sample } \\
\text { size }\end{array}$ & Design & $\begin{array}{l}\text { Instrument } \\
\text { used to } \\
\text { define SJL }\end{array}$ \\
\hline $\begin{array}{l}\text { Díaz-Morales et al } \\
2016^{36}\end{array}$ & $\begin{array}{l}\text { High school } \\
\text { students }\end{array}$ & I3.95 (I.69) & $690 / 716$ & Spain (midlatitude) & 1406 & Cross-sectional & Open questions \\
\hline $\begin{array}{l}\text { Kolomeichuk et al } \\
2016^{38}\end{array}$ & $\begin{array}{l}\text { Schoolchildren } \\
\text { and college } \\
\text { students }\end{array}$ & $10-18$ & $808 / 858$ & $\begin{array}{l}\text { Northern } \\
\text { European Russia } \\
\text { (subarctic) }\end{array}$ & 1666 & Cross-sectional & MCTQ \\
\hline $\begin{array}{l}\text { Polugrudov et al } \\
2016^{24}\end{array}$ & $\begin{array}{l}\text { General } \\
\text { population }\end{array}$ & $22(2)$ & $27 / 35$ & $\begin{array}{l}\text { Northern Asian } \\
\text { Russia (subarctic) }\end{array}$ & 62 & Cross-sectional & MCTQ \\
\hline Sheaves et al $2016^{30}$ & $\begin{array}{l}\text { Undergraduate } \\
\text { students }\end{array}$ & $21(20-23)^{c}$ & $612 / 780$ & $\begin{array}{l}\text { Southern UK } \\
\text { (midlatitude) }\end{array}$ & 1403 & Cross-sectional & MCTQ \\
\hline Silva et al $2016^{46}$ & $\begin{array}{l}\text { Undergraduate } \\
\text { students }\end{array}$ & $21.6(3.9)$ & $92 / 112$ & $\begin{array}{l}\text { Central Brazil } \\
\text { (tropical) }\end{array}$ & 204 & Cross-sectional & Open questions \\
\hline Yong et al $2016^{41}$ & $\begin{array}{l}\text { Day and shift } \\
\text { workers }\end{array}$ & $42(10)$ & $1831 / 643$ & $\begin{array}{l}\text { Germany } \\
\text { (midlatitude) }\end{array}$ & 2474 & Cross-sectional & $\begin{array}{l}\text { Modified } \\
\text { version of } \\
\text { MCTQ }\end{array}$ \\
\hline
\end{tabular}

Notes: aOnly outcomes related to SJL are described. bln the case of shift workers, midsleep on day shifts, night shifts and free days were considered. CMedian age (IQR). Abbreviations: 25-OH D, 25-hydroxyvitamin D; BDI, Beck Depression Inventory; BMI, body mass index; CAR, cortisol awakening response; CSM, composite scale of morningness; DASS-2I, Depression, Anxiety and Stress Scales; FFQ, Food Frequency Questionnaire; GPA, grade point average; HDL, high-density lipoprotein; HOMA-IR, homeostatic model assessment of insulin resistance; IL-8, interleukin-8; IQR, interquartile range; LDL, low-density lipoprotein; MCTQ, Munich ChronoType Questionnaire; MSF, midpoint of sleep on free days; MSFsc, midpoint of sleep on free days corrected for sleep debt; MSW, midpoint of sleep on work days; NI, not informed; PANAS, positive affect negative affect schedule form; SACQ, Student Adaptation to College Questionnaire; SD, standard deviation; SJL, social jetlag; SPAQ, Seasonal Pattern Assessment Questionnaire; SPEQ, Specific Psychotic Experiences Questionnaire; SRQ-20, Self-Report Questionnaire-20; STAI, state-trait anxiety inventory; TA, tense arousal; UMACL, University of Wales Institute of Science and Technology mood adjective checklist; WAI, work ability index.

states or behavioral outcomes. Furthermore, it is very likely that sleep deficit correlates with SJL. However, they are not necessarily associated, as people can still have SJL even though they do not present sleep deficit during week/work days.

A reflection on terminology is inevitable. Although transmeridional travels also lead to misalignments between endogenous and social rhythms, the expression "jetlag" would not be the best to call such disruption provoked by social routines during work/study and free days, which may lead to some confusion or misunderstanding of the term SJL. It is important to emphasize that some studies might have used the same measure of difference between the midpoints of sleep on free and on work days, but did not use the term SJL, which was first described in 2006 by Wittmann et al, ${ }^{18}$ to define it. Therefore, these studies could not be retrieved in our search. An effort should be made to standardize the nomenclature across all research fields in order to unify the literature regarding SJL. Furthermore, some studies did not meet our research criteria because they discussed SJL, but failed on reporting subjective or objective measurements of it. This reinforces the need for adequacy of what it is that we should call the biological misalignment that arises from alternated work and free days which reflects the discrepancies between the social and the biological clock. We believe that "social lag" would be more appropriate to describe this phenomenon, since the word "jet" relates to transmeridional travels. However, we suggest specialists of this area to form a joint commission to define the best nomenclature in order to guarantee the homogeneity of publications on the topic.

\section{Summary of findings}

Table 1 summarizes findings from the 26 studies included in the review.

Two cross-sectional studies evaluated obesity in large samples, measuring SJL with the Munich ChronoType Questionnaire (MCTQ), but reaching opposite conclusions. Roenneberg et $\mathrm{al}^{21}$ found that SJL increased the chance of being one of the overweight participants, with a body mass index (BMI) above or equal to $25 \mathrm{~kg} / \mathrm{m}^{2}$. Conflictingly, Johnsen et $\mathrm{al}^{22}$ found no association between SJL and obesity measures (BMI $\geq 25 \mathrm{~kg} / \mathrm{m}^{2}$, waist-to-hip ratio and abdominal obesity) when analysis was controlled for health, lifestyle and biological factors. This incongruence can be attributed to methodological differences, such as the use of self-reported 


\begin{tabular}{|c|c|c|c|}
\hline $\begin{array}{l}\text { Calculation } \\
\text { of SJL }\end{array}$ & $\begin{array}{l}\text { Calculation of } \\
\text { midpoint of sleep }\end{array}$ & Outcomes related to SJL & Study results ${ }^{a}$ \\
\hline MSF-MSW & $\begin{array}{l}\text { Midpoint between } \\
\text { bedtime and rising time }\end{array}$ & Anxiety & No correlation found with the STAI \\
\hline MSFsc-MSW & $\begin{array}{l}\text { Midpoint between sleep } \\
\text { onset and sleep end }\end{array}$ & Academic achievement & $\begin{array}{l}\text { No influence in academic achievement (assessed by an open } \\
\text { question) in a linear regression model together with average } \\
\text { sleep duration, chronotype, age and sex }\end{array}$ \\
\hline MSF-MSW & $\begin{array}{l}\text { Midpoint between sleep } \\
\text { onset and sleep end }\end{array}$ & $\begin{array}{l}\text { Circadian system state, depression, } \\
\text { anxiety, anger, obesity and cognitive } \\
\text { function }\end{array}$ & $\begin{array}{l}\text { Higher incidence of depression measured by BDI, higher wrist } \\
\text { temperature at night and lower during the day, lower wrist } \\
\text { temperature rhythm amplitude and a tendency for increase } \\
\text { in CAR; no association with BMI, waist circumference, } \\
\text { Spielberger Anxiety Inventory and Clinical Anger Scale }\end{array}$ \\
\hline MSF-MSW & $\begin{array}{l}\text { Midpoint between sleep } \\
\text { onset and sleep end }\end{array}$ & $\begin{array}{l}\text { Hallucinations, paranoia, anxiety, } \\
\text { depression, mania and hypomania }\end{array}$ & $\begin{array}{l}\text { No associations found for the following outcomes: } \\
\text { hallucinations or paranoia assessed by subscales from the } \\
\text { SPEQ; depression or anxiety, assessed by two subscales from } \\
\text { the DASS-21; mania or hypomania assessed by the Mood } \\
\text { Disorder Questionnaire }\end{array}$ \\
\hline MSF-MSW & $\begin{array}{l}\text { Midpoint between sleep } \\
\text { onset and sleep end }\end{array}$ & Inadequate diet & $\begin{array}{l}\text { Negative association with } \\
\text { servings per day of beans assessed by the FFQ }\end{array}$ \\
\hline MSF-MSWb & $\begin{array}{l}\text { Midpoint between sleep } \\
\text { onset and sleep end }\end{array}$ & Work ability & Poor WAI when SJL was associated with short sleep duration \\
\hline
\end{tabular}

data on height and weight in one study ${ }^{21}$ versus assessment of BMI variables by staff members in another, ${ }^{22}$ or to different sample characteristics, since Roenneberg et $\mathrm{al}^{21}$ studied individuals primarily from central Europe with a broader age range, while Johnsen et $\mathrm{al}^{22}$ investigated a population located at higher latitudes, above the Arctic Circle. Corroborating the hypothesis of the influence of latitude, Parsons et $\mathrm{al}^{23}$ found an association between SJL and higher BMI, fat mass and probability of being obese (BMI $\geq 30 \mathrm{~kg} / \mathrm{m}^{2}$ ) in individuals from midlatitudes, while Polugrudov et $\mathrm{al}^{24}$ found no association of SJL with BMI and waist circumference in a population living in the subarctic. Furthermore, none of these studies controlled the results for energy intake, energy expenditure or body fat. Thus, it is not possible to determine if SJL can alter BMI through an effect of increase in energy intake, or a decrease in energy expenditure, or even an impact on metabolism leading to increased fat storage. Hence, the link between SJL and obesity needs further research, but the evidence so far points to absence of such association among inhabitants of high latitudes.

Three cross-sectional studies investigated the association between SJL and metabolic risk in samples of similar age and latitude, also finding opposing results. Kantermann et $\mathrm{al}^{25}$ found no association between SJL and metabolic risk parameters in male shift workers, which may be due to the small sample size. However, Parsons et $\mathrm{al}^{23}$ found that individuals with higher SJL were more likely to meet the criteria for metabolic syndrome and Wong et $\mathrm{a}^{26}$ found higher cardiometabolic risk markers associated with higher SJL in larger samples of both sexes. Regarding the risk of cardiovascular pathologies, a positive correlation between SJL and heart rate has been demonstrated. ${ }^{27,28}$ Nonetheless, Kantermann et $\mathrm{al}^{27}$ did not find associations with arterial stiffness in male shift workers, indicating that SJL is not associated with this measure of atherosclerotic risk or that the small number of participants was not enough to find statistically significant differences. On the other hand, Rutters et $\mathrm{al}^{28}$ found higher cortisol levels and frequency of inactive periods linked to higher SJL and also reported no associations with BMI and waist measures.

Depression, one of the mood disorders most related to circadian and sleep disturbances, was evaluated in four selected studies. Levandovski et $\mathrm{al}^{29}$ found an association between SJL and higher levels of depressive symptoms in a large rural sample aged from 18 to 65 years, while Polugrudov 
et $\mathrm{al}^{24}$ found such an association in a population located in the subarctic with a mean age of 22 years. However, no association was found in young students aged between 12 and 21 years $^{12}$ or in undergraduate students of median age of 21 years. ${ }^{30}$ Depressive symptoms in young individuals may be associated with factors other than circadian misalignment (eg, puberty, hormones, sexual or emotional abuse). The associations of SJL with such outcomes might appear at the beginning of the adult life, when chronotypes tend to be the latest and, consequently, SJL is at its highest. ${ }^{31}$ This raises the question about how much time of exposure to SJL is enough to cause harm to an organism, suggesting a certain level of adaptation (like an allostatic load) that must be overcome before symptoms appear.

Findings from another study ${ }^{32}$ suggest a stronger relationship between SJL and depressive mood in individuals living in highest latitudes where sunlight varies the most across seasons. This phenomenon of drastic changes in photoperiod (the amount of time of natural light within a day) is related to winter seasonal affective disorder, a common condition among inhabitants of high latitudes characterized by an experience of depressive symptoms, mainly during winter season. ${ }^{33}$ Borisenkov et $\mathrm{al}^{32}$ found higher indication of seasonal mood variation associated with SJL in young women of subarctic zones, suggesting that the stronger unconformity between chronotype and social obligations might be related to higher susceptibility to seasonal changes in length of sunlight availability.

Jankowski ${ }^{34}$ demonstrated a positive association between SJL and tense arousal (nervous mood) in a cohort of undergraduate students, although the small sample size gives reasons to regard this findings with caution. Nonetheless, Schimitt et $\mathrm{al}^{35}$ found no significant results assessing minor psychiatric symptoms in a sample of day-shift workers. Both Díaz-Morales ${ }^{36}$ and Sheaves et $\mathrm{al}^{30}$ conducted crosssectional studies with students of midlatitudes and found no association between SJL and anxiety, assessed by different instruments in different age ranges. In addition, Polugrudov et $\mathrm{al}^{24}$ found no associations of SJL with anxiety or anger in inhabitants of high latitudes, neither did Sheaves et $a l^{30}$ with hallucinations, paranoia, mania and hypomania. Lin and $\mathrm{Yi}^{37}$ demonstrated an association of SJL with poor academic performance in a cohort of junior-high school students. Yet, the assessment through open questions and inadequate calculation of SJL by subtracting weekday bedtime from weekend bedtime make these results questionable. Kolomeichuk et $\mathrm{al}^{38}$ reported that academic achievement of schoolchildren and college students from subarctic locations did not differ according to SJL. However, studies with midlatitude samples showed a link of SJL with lower cognitive performance and lower Grade Point Average in high school students ${ }^{39}$ and poor grades during lecture term (with fixed timetables) in undergraduate students. ${ }^{40}$ Haraszti et $\mathrm{al}^{40}$ also found that this cohort of undergraduate students with higher SJL had better performance during final exams periods (with self-selected study times). This suggests that such intervals free of weekly fixed obligations provide suitable conditions for individuals that are normally out of synchrony because of regular social routines. Likewise, Yong et $\mathrm{al}^{41}$ demonstrated that, in a sample of day and shift workers, work ability is decreased the most when SJL is associated with shorter sleep duration.

Other behavioral aspects were associated with SJL in some included studies. Tavernier et $\mathrm{al}^{42}$ found no predictive effect of SJL on academic adjustment and substance use in a cohort of undergraduate students. On the other hand, substance use was a significant predictor of SJL in this study. Wittmann et al ${ }^{18}$ also evaluated the use of stimulants and demonstrated a higher probability of smoking in individuals with higher SJL. Lin and $\mathrm{Yi}^{37}$ demonstrated an association between SJL and defiant attitude, although, as mentioned above, this result must be considered with caution due to methodological inadequacies in SJL measurement. Likewise, Randler and Vollmer ${ }^{43}$ found higher physical and verbal aggression in undergraduate students with higher SJL.

In view of the close relationship between SJL and the circadian biology, Polugrudov et $\mathrm{al}^{24}$ assessed wrist temperature rhythm and Cortisol Awakening Response in order to evaluate circadian system state in a sample of individuals living in a subarctic location. Despite the small sample size, this study found higher wrist temperature at night, lower during the day, lower amplitude of wrist temperature rhythm and tendency for an increase in Cortisol Awakening Response in participants with SJL higher than or equal to 1 hour, indicating circadian system disturbances in this sample. Miller et $\mathrm{al}^{44}$ investigated positive affect rhythm as a possible mediator in the relationship between evening chronotype and depression. However, this study found no association between such rhythm and SJL measured by actigraphy. This last study represents a good evidence due to the use of an alternative complementary method to assess SJL. Subjective data assessments estimate participants' general characteristics like elemental phenotypes. Actigraphy is a useful objective method to be explored, but this technique usually assesses a limited period of time and does not represent a general pattern. 
Finally, two studies evaluated distinct outcomes that could not be compared with other samples. Choi et a ${ }^{45}$ studied epileptic and healthy participants and found lower SJL in focal epilepsy patients than healthy controls and general epilepsy patients. Silva et $\mathrm{a}^{46}$ assessed the quality of diet in undergraduate students, resulting in a negative association of SJL with servings per day of beans. Yet, the use of selfreported measures for both outcomes and SJL in these studies represents a high risk of detection bias and raises doubt about the reliability of such evidences.

\section{Publishing areas and research designs}

Most articles addressing SJL were published in biological rhythms and sleep journals. Nevertheless, disturbances of internal rhythms are thought to be risk factors for several metabolic, endocrine, behavioral and psychiatric pathologies. ${ }^{9-12}$ Thus, SJL and other forms of circadian disruption should gain more focus on journals of broader scope. The selective publication phenomenon clearly shows that discrepancies between endogenous circadian rhythms and social routines are still explored by a few research groups. SJL is a health issue that occurs on a large scale and deserves attention. For instance, the process of industrialization frequently neglects negative impacts on workers' health in order to improve profit. In addition, school schedules are dictated by parents' work schedules disregarding what would be more beneficial to students' health and academic performance. Considering the numerous epidemiological studies conducted by the scientific community, $\mathrm{SJL}$ is not a priority topic in general biomedical research. Thus, several health and behavioral risks associated with it might be neglected.

Another factor that must be taken into account is study design. About $80 \%$ of the articles analyzed are crosssectional studies. That is, measurements are performed in a single timepoint of participants' life. This observational design does not allow the establishment of causality between factors and outcomes assessed. In other words, it is not possible to determine if SJL is the cause of illness states, or if these health and behavioral variables lead to SJL. We can only assume that there is an association among some of them, but further longitudinal research is required to determine the direction of such association. Biological mechanisms involved in circadian system regulation are a growing area of study. Furthermore, most outcomes found in Table 1 are multifactorial. Therefore, establishing if SJL acts as cause or consequence of ill health states is essential to acquire better knowledge on the pathophysiology of circadian disruption.

\section{Methodological heterogeneity}

A strong limitation that restricts the possibility of inferences from the present results is the high methodological heterogeneity. Studies methodologies mainly differ in three ways:

1. instruments used to calculate SJL, reflecting on the accuracy of information retrieved, ie, SJL measured objectively by actigraphy or self-reported by questionnaire data;

2. computation of SJL;

3. definition of what it is that should be considered SJL, ie, the total amount of mismatch time, or the establishment of cutoff values;

4. duration of the study and latitude of studies, comprising assessments in different photoperiods and seasons of the year.

Most studies used MCTQ or its validated adaptation for shift workers (MCTQ-shift), but some used open questions or adapted MCTQ questions. Although MCTQ psychometric properties have not yet been assessed, ${ }^{47}$ studies have shown the reliability of its parameters in comparison to sleep logs, ${ }^{48}$ actigraphy, ${ }^{49}$ Morningness-Eveningness Questionnaire, ${ }^{50,47}$ and Dim Light Melatonin Onset. ${ }^{51}$ MCTQ considers the difference between bedtime and sleep onset time, and between rise time and wake up time. Furthermore, SJL is a construct derived from MCTQ-based sleep parameters. Therefore, the distinction of sleep and bed timing, which can be standardized by MCTQ, is crucial for a reliable measure. We believe that the studies that formulated their questions disregarding such distinction are at risk of reporting a biased SJL assessment.

One study ${ }^{37}$ did not calculate SJL through the conventional formula, but by subtracting weekday bedtime from weekend bedtime. Someone who goes to bed at the same time on work and free days, but wakes up much later on free days has a strong misalignment between chronotype and social routine. This situation is contemplated by measuring differences in midpoints of sleep, but not by comparing bedtimes. Two other studies ${ }^{36,39}$ also calculated midpoints of time in bed as a proxy for midpoint of sleep, and another ${ }^{42}$ operationalized the midpoint of sleep as the halfway point between bedtime and wake time. Therefore, results on SJL from such studies should be regarded with caution. Additionally, some studies calculated SJL using a correction of MSF for sleep debt. ${ }^{22,38}$ This correction is typically used to estimate chronotype, but is not necessary (and not recommended) for measurement of SJL.

In addition, study results are based mostly on self-reported measures, such as questionnaires and sleep logs. People who 
volunteer to participate in researches regarding sleep might represent the population sample that is most concerned about the topic. Therefore, overestimation of sleep-related problems and wrong perceptions of sleep-awakening schedules can be important sources of bias. Furthermore, most people might also overestimate sleep latency, therefore interfering in selfreported sleep time. Only two studies used objective methods to evaluate SJL (eg, actigraphy). Although not as useful as questionnaires to assess general sleep features, actigraphy is a good alternative to objectively evaluate daily motor activity, light exposure and other parameters of importance to biological rhythms. ${ }^{52,53}$

Some studies attempt to establish a relevant and useful cutoff value, representing a certain number of hours (or minutes) of SJL that would have stronger association with adverse outcomes. For example, Rutters et $\mathrm{al}^{28}$ showed that individuals suffering from an $\mathrm{SJL} \geq 2$ hours had worse endocrine and cardiovascular risk profiles, compared to those who had an $\mathrm{SJL} \leq 1$ hour. Levandovski et $\mathrm{al}^{29}$ also reported more depressive symptoms in participants with more than 2 hours of SJL in comparison to the rest of the population. Johnsen et $\mathrm{al}^{22}$ excluded participants who presented an $\mathrm{SJL} \leq 3$ hours. Since there is still no consensus as to what would be the best cutoff value of SJL for health and behavioral research, future studies should analyze SJL both as a continuous and as a categorical variable.

Most cross-sectional studies had durations of more than 4 months, assessing SJL in different seasons of the year. Since the circadian system is strongly influenced by seasonality and photoperiod, ${ }^{54}$ internal circadian rhythmicity and, conse- quently, SJL might change within a few months. This can be a confounding factor, increasing the risk of bias. In addition, Figure 3 shows the different settings of studies, highlighting the diversity of latitudes that might influence the study results because of photoperiod and seasonal variations. Notably, higher latitudes present more pronounced photoperiod changes throughout the year, when compared to equatorial and tropical zones. ${ }^{32}$ It is important to either measure SJL controlling for season of assessment and latitude, or take these factors into consideration when performing statistical analysis and discussing results.

\section{Accounts on the diversity of circadian biology}

As chronotypes vary according to age, ${ }^{31}$ it is very likely that outcomes associated with SJL also change depending on it. Therefore, studies investigating the same parameters in samples of different age ranges (eg, children and elderly) might reach different conclusions. For example, Levandovski et $\mathrm{al}^{29}$ found an association between SJL and depression in an adult sample (from 18 to 65 years), while de Souza and Hidalgo $^{12}$ found no such association in young students (from 12 to 21 years). Even though several factors might play a role in this difference, SJL age dependence should always be considered.

Moreover, it is known that circadian typologies are different between men and women. ${ }^{31}$ In addition, some work activities that are culturally attributed to women (eg, domestic services and babysitting) are not necessarily considered as formal labor activities. Such activities need to be taken

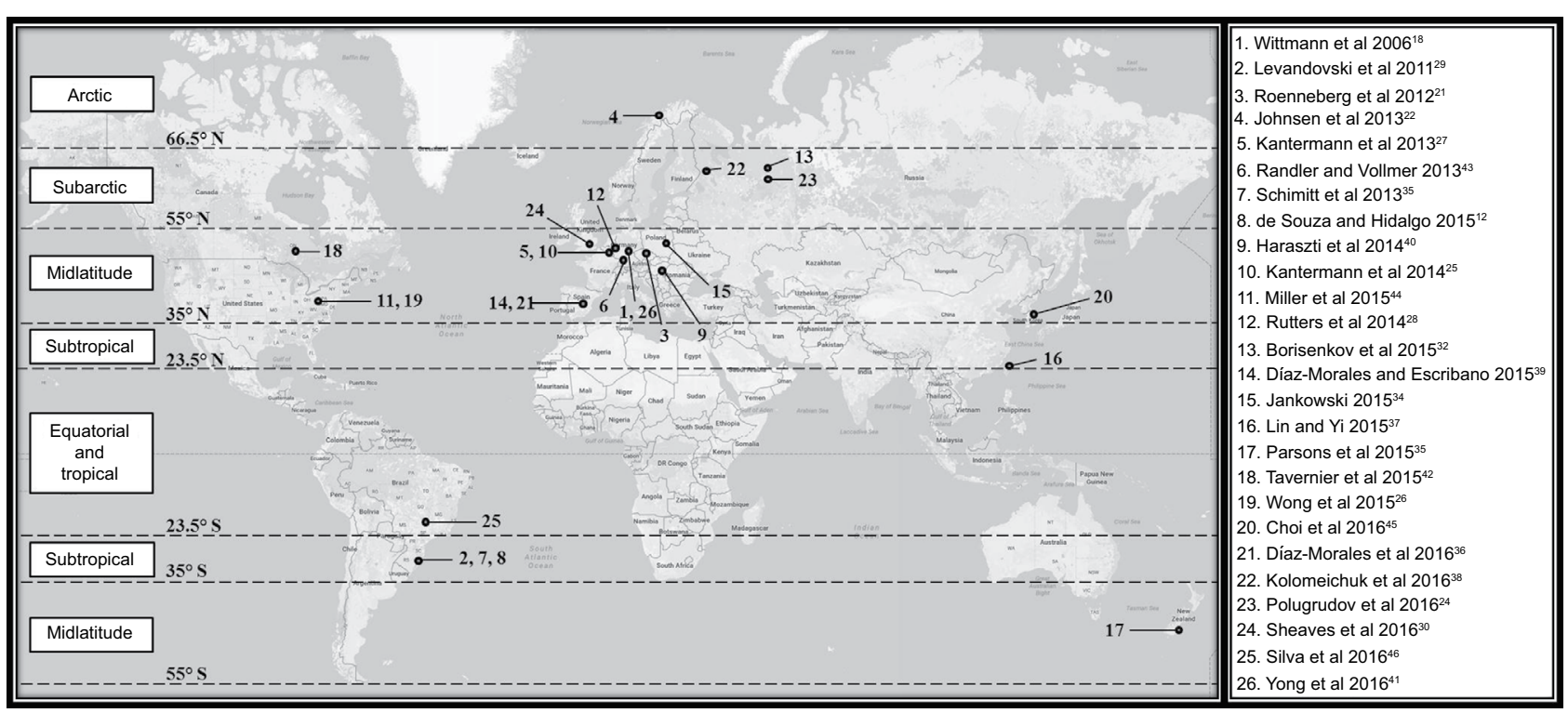

Figure 3 Distribution of studies across latitude zones. 
into account for an accurate evaluation of SJL, as they are prevalent and tend to occur even on free days.

Since SJL is necessarily associated with contrasting social schedules within a week period, it is important to consider further characterization of sociodemographic data, including work status, education level, behaviors and traditions of samples. For example, some studies retrieved in our search distinguish rural from urban populations. These social organizations have marked differences in terms of social activity schedules. Rural populations have different lifestyles and circadian patterns that could influence measurements of SJL. ${ }^{55,56}$ Most studies do not present a clear description of their samples in terms of research setting, cultural background and work situation. Part of these studies could have been conducted in rural populations and/or with unemployed individuals who had freedom to choose sleep timing. These characteristics can distort SJL analysis and its relation to health and behavior outcomes. Finally, any medical condition (including psychiatric affections) that could disturb sleep/wake schedules should be assessed as a confounding factor. It is likely that part of these studies was conducted in rural populations, therefore distorting SJL analysis and its relation to health and behavior outcomes.

\section{Conclusion}

Our results point to a variety of health and behavioral outcomes that seem to be associated with the mismatch existent between work or study days and free days. Our search highlights mainly neuropsychiatric disturbances. They are epilepsy, minor psychiatric symptoms, aggression and conduct problems, mood disorders, cognitive impairment (eg, work and academic performance) and substance use. Additionally, SJL has been associated with increased cardiometabolic risk and adverse endocrine profiles in some studies.

However, there is still lack of consensus on the associations reported, methodological flaws and lack of high-level evidence. To the present moment, SJL was studied only in a restricted amount of samples. Current evidence on SJL regards to individuals thought to be at risk of circadian disruption because of weekly activity routines (eg, shift workers, undergraduate and college students). The incongruences in reported results might be due to the high heterogeneity of methodologies applied or to the low similarities among the populations studied (eg, young students from a rural setting versus shift workers from high-latitude locations). This highlights the need for methodological adequacy in order to determine 1) if differences observed are, in fact, reflecting singularities of samples, which would suggest the existence of factors modulating SJL differently in each of these populations or 2) if they are mere methodological or statistical artifacts. It is worth emphasizing that SJL measurement and calculation can be done in a simple, cheap and fast way. Given the growing concern about the effects of modern lifestyles on health, more resources should be destined to large, population-based longitudinal studies, preferably with instruments for objective measures of MSF. Future research should aim to prospectively identify health and behavioral outcomes associated with SJL and determine the time of exposure and the number of hours of SJL necessary to represent a risk.

Whereas humans are social beings and modern lifestyles are demanding gradually more adaptation of individuals to routines that do not respect chronotypes, social cues are increasingly gaining attention in chronobiology research. The effects of circadian disruption are new in the course of human evolution, but its possible hazards are of interest to several areas of medicine, such as psychiatry, endocrinology, immunology and oncology. Therefore, it should be included in future research agenda of different biomedical sectors.

\section{Disclosure}

The authors report no conflicts of interest in this work.

\section{References}

1. Brechtold DA, Gibbs JE, Loudon AS. Circadian dysfunction in disease. Trends Pharmacol Sci. 2010;31(5):191-198.

2. Zhang J, Kaasik, K, Blackburn MR, Lee CC. Constant darkness is a circadian metabolic signal in mammals. Nature. 2006;439(7074):340-343.

3. Ehlers CL, Frank E, Kupfer DJ. Social zeitgebers and biological rhythms. A unified approach to understanding the etiology of depression. Arch Gen Psychiatry. 1988;45(10):948-952.

4. Grandin LD, Alloy LB, Abramson LY. The social zeitgeber theory, circadian rhythms, and mood disorders: review and evaluation. Clin Psychol Rev. 2006;26(6):679-694.

5. Soreca I, Frank E, Kupfer DJ. The phenomenology of bipolar disorder: what drives the high rate of medical burden and determines long-term prognosis? Depress Anxiety. 2009;26(1):73-82.

6. McEwen BS, Karatsoreos IN. Sleep deprivation and circadian disruption: stress, allostasis, and allostatic load. Sleep Med Clin. 2015;10(1):1-10.

7. Adan A, Archer SN, Hidalgo MP, Di Milia L, Natale V, Randler C. Circadian typology: a comprehensive review. Chronobiol Int. 2012;29(9): $1153-1175$.

8. Amaral FG, Castrucci AM, Cipolla-Neto J, et al. Environmental control of biological rhythms: effects on development, fertility and metabolism. J Neuroendocrinol. 2014;26(9):603-612.

9. Antunes LC, Levandovski R, Dantas G, Caumo W, Hidalgo MP. Obesity and shift work: chronobiological aspects. Nutr Res Rev. 2010;23(1):155-168.

10. Cipolla-Neto J, Amaral FG, Afeche SC, Tan DX, Reiter RJ. Melatonin, energy metabolism, and obesity: a review. J Pineal Res. 2014;56(4): 371-381.

11. Wang P, Ren FM, Lin Y, et al. Night-shift work, sleep duration, daytime napping, and breast cancer risk. Sleep Med. 2015;16(4):462-468.

12. de Souza CM, Hidalgo MP. The midpoint of sleep on working days: a measure for chronodisruption and its association to individuals' wellbeing. Chronobiol Int. 2015;32(3):341-348. 
13. Erren TC, Reiter RJ. Defining chronodisruption. J Pineal Res. 2009; 46(3):245-247.

14. Wulff K, Gatti S, Wettstein JG, Foster RG. Sleep and circadian rhythm disruption in psychiatric and neurodegenerative disease. Nat Rev Neurosci. 2010;11(8):589-599.

15. Reutrakul S, Knutson KL. Consequences of circadian disruption on cardiometabolic health. Sleep Med Clin. 2015;10(4):455-468.

16. Akerstedt T, Hume K, Minors D, Waterhouse J. Good sleep-its timing and physiological sleep characteristics. J Sleep Res. 1997;6(4):221-229.

17. Rosipal R, Lewandowski A, Dorffner G. In search of objective components for sleep quality indexing in normal sleep. Biol Psychol. 2013; 94(1):210-220.

18. Wittmann M, Dinich J, Merrow M, Roenneberg T. Social jetlag: misalignment of biological and social time. Chronobiol Int. 2006;23(1-2): 497-509.

19. Baron KG, Reid KJ. Circadian misalignment and health. Int Rev Psychiatry. 2014;26(2):139-154.

20. Higgins JPT, Green S, editors. Cochrane Handbook for Systematic Reviews of Interventions Version 5.1.0 [updated March 2011]. The Cochrane Collaboration; 2011. Available from: http://handbook. cochrane.org. Accessed May 30, 2016.

21. Roenneberg T, Allebrandt KV, Merrow M, Vetter C. Social jetlag and obesity. Curr Biol. 2012;22(10):939-943.

22. Johnsen MT, Wynn R, Bratlid T. Optimal sleep duration in the subarctic with respect to obesity risk is 8-9 hours. PLoS One. 2013;8(2):e56756.

23. Parsons MJ, Moffitt TE, Gregory AM, et al. Social jetlag, obesity and metabolic disorder: investigation in a cohort study. Int J Obes (Lond). 2015;39(5):842-848.

24. Polugrudov AS, Panev AS, Smirnov VV, Paderin NM, Borisenkov MF, Popov SV. Wrist temperature and cortisol awakening response in humans with social jetlag in the North. Chronobiol Int. 2016;33(7):802-809.

25. Kantermann T, Duboutay F, Haubruge D, et al. The direction of shiftwork rotation impacts metabolic risk independent of chronotype and social jetlag-an exploratory pilot study. Chronobiol Int. 2014; 31(10):1139-1145.

26. Wong PM, Hasler BP, Kamarck TW, Muldoon MF, Manuck SB. Social jetlag, chronotype, and cardiometabolic risk. J Clin Endocrinol Metab. 2015;100(12):4612-4620.

27. Kantermann T, Duboutay F, Haubruge D, Kerkhofs M, Schmidt-Trucksäss A, Skene DJ. Atherosclerotic risk and social jetlag in rotating shiftworkers: first evidence from a pilot study. Work. 2013;46(3):273-282.

28. Rutters F, Lemmens SG, Adam TC, et al. Is social jetlag associated with an adverse endocrine, behavioral, and cardiovascular risk profile? J Biol Rhythms. 2014;29(5):377-383.

29. Levandovski R, Dantas G, Fernandes LC, et al. Depression scores associate with chronotype and social jetlag in a rural population. Chronobiol Int. 2011;28(9):771-778.

30. Sheaves B, Porcheret K, Tsanas A, et al. Insomnia, nightmares, and chronotype as markers of risk for severe mental illness: results from a student population. Sleep. 2016;39(1):173-181.

31. Roenneberg T, Kuehnle T, Juda M, et al. Epidemiology of the human circadian clock. Sleep Med Rev. 2007;11(6):429-438.

32. Borisenkov MF, Petrova NB, Timonin VD, et al. Sleep characteristics, chronotype and winter depression in 10-20-year-olds in northern European Russia. J Sleep Res. 2015;24(3):288-295.

33. Nunn CL, Samson DR, Krystal AD. Shining evolutionary light on human sleep and sleep disorders. Evol Med Public Health. 2016;2016(1): 227-243.

34. Jankowski KS. Is the shift in chronotype associated with an alteration in well-being? Biol Rhythm Res. 2015;46(2):237-248.

35. Schimitt R, Levandovski R, Hidalgo MP. Relations between social rhythm, sleep phase, and minor psychiatric symptoms in healthy workers. Biol Rhythm Res. 2013;44(3):403-409.
36. Díaz-Morales JF. Anxiety during adolescence: considering morningness-eveningness as a risk factor. Sleep Biol Rhythms. 2016;14(2): 141-147.

37. Lin WH, Yi CC. Unhealthy sleep practices, conduct problems, and daytime functioning during adolescence. J Youth Adolesc. 2015; 44(2):431-446.

38. Kolomeichuk SN, Randler C, Shabalina I, Fradkova L, Borisenkov M. The influence of chronotype on the academic achievement of children and adolescents-evidence from Russian Karelia. Biol Rhythm Res. 2016;47(6):873-883.

39. Díaz-Morales JF, Escribano C. Social jetlag, academic achievement and cognitive performance: understanding gender/sex differences. Chronobiol Int. 2015;32(6):822-831.

40. Haraszti RÁ, Ella K, Gyöngyösi N, Roenneberg T, Káldi K. Social jetlag negatively correlates with academic performance in undergraduates. Chronobiol Int. 2014;31(5), 603-612.

41. Yong M, Fischer D, Germann C, Lang S, Vetter C, Oberlinner C. Are chronotype, social jetlag and sleep duration associated with health measured by work ability index? Chronobiol Int. 2016;33(6):721-729.

42. Tavernier R, Munroe M, Willoughby T. Perceived morningness eveningness predicts academic adjustment and substance use across university, but social jetlag is not to blame. Chronobiol Int. 2015;32(9): 1233-1245.

43. Randler C, Vollmer C. Aggression in young adults - a matter of short sleep and social jetlag? Psychol Rep. 2013;113(3):754-765.

44. Miller MA, Rothenberger SD, Hasler BP, et al. Chronotype predicts positive affect rhythms measured by ecological momentary assessment. Chronobiol Int. 2015;32(3):376-384.

45. Choi SJ, Joo EY, Hong SB. Sleep-wake pattern, chronotype and seizures in patients with epilepsy. Epilepsy Res. 2016;120:19-24.

46. Silva CM, Mota MC, Miranda MT, Paim SL, Waterhouse J, Crispim CA. Chronotype, social jetlag and sleep debt are associated with dietary intake among Brazilian undergraduate students. Chronobiol Int. 2016;33(6):740-748.

47. Di Milia L, Adan A, Natale V, Randler C. Reviewing the psychometric properties of contemporary circadian typology measures. Chronobiol Int. 2013;30(10):1261-1271.

48. Roenneberg T, Wirz-Justice A, Merrow M. Life between clocks: daily temporal patterns of human chronotypes. J Biol Rhythms. 2003; 18(1):80-90.

49. Jankowski KS. Validation of the Munich ChronoType Questionnaire against actigraphy. Int J Psychophysiol. 2016;108:149.

50. Zavada A, Gordijn MC, Beersma DG, Daan S, Roenneberg T. Comparison of the Munich Chronotype Questionnaire with the HorneOstberg's morningness-eveningness score. Chronobiol Int. 2005;22: 267-278.

51. Kantermann T, Sung H, Burgess HJ. Comparing the Morningnesseveningness Questionnaire and Munich ChronoType Questionnaire to the dim light melatonin onset. $J$ Biol Rhythms. 2015;30(5): 449-453.

52. de Souza L, Benedito-Silva AA, Pires ML, Poyares D, Tufik S, Calil HM. Further validation of actigraphy for sleep studies. Sleep. 2003;26(1): $81-85$.

53. Martin JL, Hakim AD. Wrist actigraphy. Chest. 2011;139(6):1514-1527.

54. Quiles CL, de Oliveira MA, Tonon AC, Hidalgo MP. Biological adaptability under seasonal variation of light/dark cycles. Chronobiol Int. 2016;33(8):964-971.

55. Suliburska J, Bogdański P, Pupek-Musialik D, Głód-Nawrocka M, Krauss H, Piątek J. Analysis of lifestyle of young adults in the rural and urban areas. Ann Agric Environ Med. 2012;19(1):135-139.

56. Carvalho FG, Hidalgo MP, Levandovski R. Differences in circadian patterns between rural and urban populations: an epidemiological study in countryside. Chronobiol Int. 2014;31(3):442-449. 
ChronoPhysiology and Therapy is an international, peer-reviewed, open access journal focusing on research into the cyclic variations and rhythmicity in physiological processes in the body and the research and development and optimal timing of administration of therapeutic targets to achieve improved outcomes and quality of life for the patient. The manuscript management system is completely online and includes a very quick and fair peer-review system. Visit http://www.dovepress.com/ testimonials.php to read real quotes from published authors.

Submit your manuscript here: https:/www.dovepress.com/chronophysiology-and-therapy-journal 